\title{
The Ability of Spontaneous Autogamy in Four Orchid Species: Cephalanthera rubra, Neottia ovata, Gymnadenia conopsea, AND Platanthera bifolia
}

\author{
Izabela TaŁaŁaJ*, Beata Ostrowiecka, Ewa WŁostowska, \\ AgNiEszKa RutKowsKa AND EMILIA BRzOSKO
}

\author{
Department of Plant Ecology, Institute of Biology, University of Biatystok, \\ ul. K. Ciołkowskiego 1J, 15-245 Biatystok, Poland
}

Received February 28, 2017; revision accepted June 13, 2017

\begin{abstract}
The breeding system in Orchidaceae generates many questions about the selfing potential of its representatives. We investigated the ability of spontaneous autogamy of four orchid species: Cephalanthera rubra and Neottia ovata of the Neottieae tribe and Gymnadenia conopsea and Platanthera bifolia of the Orchideae tribe. These species represent diverse specializations of the gynostemium architecture. The self-compatibility and properties of autogamous seeds were determined in a bagging experiment and seed development analysis. After induced autogamy, a high level of fruiting (80-100\%) was noted in all of the four study species. C. rubra, N. ovata, and G. conopsea are completely self-compatible, and $P$. bifolia is suggested to be partially self-compatible. If autogamy occurred, inbreeding depression and resource limitation on seed development appeared only in the two Orchideae species. Independent of flower specialization, both Neottieae species and P. bifolia were completely allogamous, whereas G. conopsea could be facultatively autogamous.
\end{abstract}

Keywords: allogamous species, facultative autogamy, fruit set, hand pollination, seed development, self-compatibility

\section{INTRODUCTION}

Orchidaceae represents an interesting plant group, in which a dramatic radiation began after the mass extinction event at the Cretaceous/Tertiary boundary (Ramírez et al., 2007). At least 19,500 orchid species have been classified (Peakall, 2007), which distinguishes this family as one of the largest among angiosperms. One of the evolutionary processes that lead to speciation of this family is the frequently observed transition to spontaneous autogamy (Pedersen and Ehlers, 2000; Bateman, 2001; Charlesworth, 2006). Spontaneous selfpollination is sometimes observed in animalpollinated plants when the environment is subject to changes such as anthropogenic habitat fragmentation (Barrett and Shore, 1989; Eckert et al., 2009) or periods of unfavorable climatic conditions (Liu et al., 2006). This transition has also been recorded in some plants that have migrated to new areas outside their previous range
(Catling, 1990; Etcheverry et al., 2003; Barrett et al., 2008).

When autogamy resulting from spontaneous self-pollination takes place, it should guarantee reproductive assurance in most cases (Kalisz and Vogler, 2003). Among Orchidaceae, autogamous flowers are easy to verify due to morphological changes that eliminate mechanical barriers between male and female structures of the column (Pedersen and Ehlers, 2000; Squirrell et al., 2002; Gale, 2007). Self-pollination may also be caused by proactive or facilitated floral movements (Liu et al., 2006; Claessens and Kleynen, 2011), and it is also sometimes connected with unusual processes such as cryptic pollen germination (Bonatti et al., 2006). Such adaptations may be obligatory and determine spontaneous autogamy as the sole pollination mechanism. They may take place before anthesis in cleistogamous flowers, such as Epipactis microphylla (Bonatti et al., 2006), or during anthesis in chasmogamous flowers, as in Epipactis

\footnotetext{
* Corresponding author, email: izagry@uwb.edu.pl
} 
helleborine subsp. neerlandica (Pedersen and Ehlers, 2000), Holcoglossum amesianum (Liu et al., 2006) or Ophrys apifera (Darwin, 1877).

Very often, autogamy is facultative and selfpollination takes place in the final phase of flowering, as in Epipactis helleborine var. papillosa and var. sayekiana (Suetsugu, 2013), Epipactis palustris (Tałałaj and Brzosko, 2008) and Nervilia nipponica (Gale, 2007). Facultative autogamy may occur in a number of orchids, but the mechanism facilitating self-pollination is difficult to determine (Catling, 1990; Claessens and Kleynen, 2011). In plants, the possibility of facultative autogamy is a consequence of a low frequency of pollinators, and floral traits related to this type of selfing may change at different times of anthesis. Thus, the appearance and extent of facultative autogamy could vary between populations of a given species or even between years within the same population, and it may therefore be overlooked (Kalisz et al., 1999; Claessens and Kleynen, 2011).

Before describing facultative autogamy in operation (sensu Lloyd and Schoen, 1992), we should make certain that a particular orchid species is structurally capable of self-pollination (Catling, 1990). Moreover, to investigate the full evolutionary potential of this process, studies covering a geographically wide range of habitats are needed. Such investigations have very often been disregarded, and information about breeding systems of orchids is therefore incomplete. The information is often obtained from a single population and is usually based on observations or suggestions without any empirical data. The same problem is also connected with the degree of selfcompatibility. Orchids have been considered to be self-compatible (Tremblay et al., 2005; Claessens and Kleynen, 2011). However, many of them are partially self-compatible (Johnson and Nilsson, 1999). This is identified when self-pollination generates fruits with a significant reduction of the seed set (Johnson and Nilsson, 1999), but there are limited literature sources with analysis of the subject.

Numerous widely distributed orchids from the North Temperate Zone belong to the Neottieae and Orchideae tribes (Pridgeon et al., 2001; Pridgeon et al., 2005). The Neottieae tribe (subfamily Epidendroideae) is a relatively primitive group. Primitiveness results from features that include: 1) erect or subincumbent anthers with a flexible connection to the column base, 2) soft structure of the pollinia formed by monads and tetrads of similar structure, 3) a very primitive type of rostellum (if present), and 4) a unique semi-liquid character of the viscidium (if present) (Szlachetko, 1995; Pridgeon et al., 2005). The very simple gynostemium has caused a large amount of the morphological variation as an adaptation to local pollinator availability, which are predominantly Hymenopterans and Dipterans (Claessens and Kleynen, 2011). Therefore, multiple transitions from allogamy to facultative or obligate autogamy are well known in Neottieae (Squirrell et al., 2002). A review by Claessens and Kleynen (2011) indicates that the most important factors that promote autogamy in this tribe are: 1) pollen fragments falling onto the stigmatic surface, 2) an ineffective or absent rostellum, and 3 ) reduction of the clinandrium.

The Orchideae tribe (subfamily Orchidoideae) contains orchids with two or four sectile pollinia, which are attached by prominent caudicles to one or two viscidia (Szlachetko, 1995; Pridgeon et al., 2001). Putatively specialized developments of the particular characters have been observed in this tribe: 1) a bilocular anther that is firmly attached to the rest of the column, 2) a deeply three-lobed rostellum with mid-lobe erect and lying between or in front of the anther loculi, and 3) a spurrred, frequently three-lobed lip (Pridgeon et al., 2001). Floral features and pollinator observations indicate that sphingophilous and phalaenophilous syndromes predominate in this group (Dressler, 1981). Such an adaptation suggests that autogamy is usually accidental in Orchideae, and it happens at a late stage of flower development in most cases because of bending of the caudicles, pollen fragments, or the entire pollinium falling onto the stigmatic surface (Claessens and Kleynen, 2011).

Among the 80 species of the Neottieae tribe, two widely distributed orchid species are Neottia ovata and Cephalanthera rubra (Pridgeon et al., 2005). Among the approximately 1800 species of the Orchideae tribe, two relatively common taxa are Gymnadenia conopsea and Platanthera bifolia (Pridgeon et al., 2001). There is a common view that these species are allogamous (Nilsson, 1983a,b; Nazarov, 1995; Gustafsson, 2000; Brys et al., 2008), but some reports have described each of them as being capable of autogamy (Hagerup, 1952; Kugler, 1963; Nilsson, 1981; Meyer et al., 2007; Claessens et al., 2015), which has raised the question of possible spontaneous selfpollination. Furthermore, empirical data describing self-compatibility are scarce for particular species (Nilsson, 1981; Nilsson, 1983a,b; Brys et al., 2008; Boberg and Ågren, 2009). Therefore, we evaluated the potential and limitations of facultative autogamy in these species. This study is a part of broader investigations on the breeding system of temperate orchids in populations located in a continuous range of their geographical distribution and in natural habitats characteristic of northeast Poland (Tałałaj and Brzosko, 2008). We attempted to evaluate the self-compatibility of a given species 
with focus on the fruit set and the properties of seeds from experimentally self-pollinated flowers. Specifically, we examined whether spontaneous autogamy may occur facultatively under pollinator limitation in the study populations.

\section{MATERIALS AND METHODS}

\section{STUDIED SPECIES}

Cephalanthera rubra (L.) RICH. is a fairly shade-tolerant forest herb (Summerhayes, 1951; Vakhrameeva et al., 2008) that is widely distributed in Europe and a significant part of Asia (Vakhrameeva et al., 2008). Flowers of C. rubra are large and rose-colored, with a complete lack of scent and nectar, thus attracting pollinators by deceit (Nilsson, 1983b). Effective pollination depends on solitary bees, particularly Chelostoma spp. (Nilsson, 1983b; Nazarov and Ivanov, 1990; Newman et al., 2007) and weevil species Miarus campanulae (Claessens et al., 2015), whose behavior is strictly associated with Campanula flowers. The perianth of $C$. rubra mimics the visual spectral range of Campanula petals, and it peaks in anthesis before Campanula (Nilsson, 1983b).

Neottia ovata (L.) BLOFF ET FINGERH. (formerly Listera ovata) is usually a shade-tolerant, longlived forest herb. The general distribution area of the species covers all of Europe and reaches the south-western part of eastern Siberia (Kotilínek et al., 2015). Flowers are yellow-green with a large amount of nectar and sweet scent until the end of anthesis (Percival, 1961; Nilsson, 1981). These attractants are very effective and stimulate an extremely large number of insects from various pollinator groups. Nilsson observed 283 species in Swedish populations (Nilsson, 1981). However, the flowers of $N$. ovata are highly specialized to comparatively unspecialized anthophilous insects, such as Ichneumonidae (Nilsson, 1981).

Gymnadenia conopsea (L.) R. BR. is a perennial species with a wide range that occurs in both well-lit open meadows and significantly shaded sites. The species is distributed throughout Europe and a considerable part of Asia (Vakhrameeva et al., 2008). Different cytotypes of G. conopsea often form mixed-ploidy populations (Marhold et al., 2005; Jersáková et al., 2010; Stark et al., 2011). The population that we have studied comprises only diploids (Trávníček et al., 2012). Flowers are small and pinkish or reddish lilac with a large amount of nectar in the narrow spur and a weak vanilla-like scent emitted during the day and night (Stpiczyńska and Matusiewicz, 2001; Marhold et al., 2005; Bell et al., 2009). Generally, the flowers of $G$. conopsea are adapted to diverse Lepidopterans, but nocturnal moths are the most effective pollen vectors (Vöth, 2000; Meyer et al., 2007).

Platanthera bifolia (L.) RICH. is a longlived species that occurs in a variety of forest and meadow habitats. In Europe, the species is distributed from Norway to the Balkans, and it has been found in a significant portion of Asia (Vakhrameeva et al., 2008). Each flower on the inflorescence is intensely white with a slender nectariferous spur, and a fragrance is emitted periodically in the evening (Maad and Nilsson, 2004; Boberg and Ågren, 2009). These attractants stimulate the feeding behavior of nocturnal Lepidoptera, particularly Sphingidae and Noctuidae (Nilsson, 1983a).

\section{STUDY SITES}

Field work was carried out in the north-eastern part of Poland in the Biebrza river valley, which is known as the largest complex of swamps in Europe. The study populations comprise one population of C. rubra and one population of G. conopsea (both species are represented by single populations in the study area) as well as two populations of $N$. ovata and two of $P$. bifolia. The populations are situated on three mineral islands: Zabudnik (ZAB), Oparzelisko (OPA), and Pogorzały (POG), which are elevated at approximately $1 \mathrm{~m}$ above the peat level (Tab. 1). OPA lies adjacent to POG, and both are located about $4 \mathrm{~km}$ apart from ZAB. These mineral islands differ in history, shape (Źurek, 1991), and vegetation cover (Tab. 1). In spite of the close proximity of these islands, they show differences in time of flowering and fruiting, as well as in pollinator communities and activity (Brzosko, 2002; Tałałaj and Brzosko, 2008).

\section{HAND POLLINATION EXPERIMENTS}

From 2007 to 2008, induced and spontaneous autogamy experiments were performed in each population using standard protocols for plants (Dafni, 1992). However, the spontaneous autogamy experiment was extended to the period of 2009 to 2010 to revise controversial data for $N$. ovata in one population (Tab. 2). In both the induced and autonomous experiments, inflorescences were covered by a nylon mesh bag from the bud stage until the end of anthesis to exclude pollinators. For a particular treatment, five inflorescences were selected each year in each population. Unfortunately, many of them were damaged by moose, which reduced the number of inflorescences in the final analysis (Tab. 2).

The result of within-flower self-pollination was tested by hand self-pollination. During the bagging experiment, we used all the flowers 
TABLE 1. Descriptions of sites.

\begin{tabular}{|c|c|c|c|}
\hline Pop. & Species & Plant community & $\begin{array}{l}\text { Geographical } \\
\text { coordinates }\end{array}$ \\
\hline ZAB1 & $\begin{array}{l}\text { N. ovata } \\
\text { P. bifolia }\end{array}$ & $\begin{array}{l}\text { Fragment of oak-linden-hornbeam forest (Tilio-Carpinetum) and shrub } \\
\text { patches with dominance of Rhamnus cathartica and Frangula alnus. }\end{array}$ & $\begin{array}{l}53^{\circ} 17^{\prime} 56^{\prime \prime} \mathrm{N} \\
22^{\circ} 35^{\prime} 09^{\prime \prime} \mathrm{E}\end{array}$ \\
\hline ZAB2 & G. conopsea & $\begin{array}{l}\text { Open area with tufted grasses and sedges at the border between mineral } \\
\text { elevation and peat bog. }\end{array}$ & $\begin{array}{l}53^{\circ} 29^{\prime} 81^{\prime \prime} \mathrm{N} \\
22^{\circ} 57^{\prime} 86^{\prime \prime} \mathrm{E}\end{array}$ \\
\hline POG & P. bifolia & $\begin{array}{l}\text { Fertile type of oak-linden-hornbeam forest (Tilio-Carpinetum) } \\
\text { with high density of shrubs. }\end{array}$ & $\begin{array}{l}53^{\circ} 18^{\prime} 24^{\prime \prime} \mathrm{N} \\
22^{\circ} 31^{\prime} 11^{\prime \prime} \mathrm{E}\end{array}$ \\
\hline OPA1 & N. ovata & $\begin{array}{l}\text { Herb layer typical of hornbeam forest with Mercurialis perennis } \\
\text { as the dominant species; the stand built of birch trees. }\end{array}$ & $\begin{array}{l}53^{\circ} 18^{\prime} 30^{\prime \prime} \mathrm{N} \\
22^{\circ} 32^{\prime} 11^{\prime \prime} \mathrm{E}\end{array}$ \\
\hline OPA2 & C. rubra & $\begin{array}{l}\text { Open area with dominance of grasses and the border of large aggregation of } \\
\text { Corylus avellana and Tilia cordata. }\end{array}$ & $\begin{array}{l}53^{\circ} 18^{\prime} 41^{\prime \prime} \mathrm{N} \\
22^{\circ} 32^{\prime} 12^{\prime \prime} \mathrm{E}\end{array}$ \\
\hline
\end{tabular}

TABLE 2. Fruit set following bagging experiment.

\begin{tabular}{|c|c|c|c|c|c|c|c|}
\hline \multicolumn{8}{|c|}{ Neottieae } \\
\hline \multicolumn{3}{|c|}{ Cephalanthera rubra } & \multicolumn{5}{|c|}{ Neottia ovata } \\
\hline \multirow{2}{*}{ year } & \multirow{2}{*}{$\begin{array}{c}\begin{array}{c}\text { Induced } \\
\text { autogamy }\end{array} \\
\text { OPA2 }\end{array}$} & \multirow{2}{*}{$\begin{array}{c}\begin{array}{c}\text { Spontaneous } \\
\text { autogamy }\end{array} \\
\text { OPA2 }\end{array}$} & \multirow{2}{*}{ year } & \multicolumn{2}{|c|}{$\begin{array}{c}\text { Induced } \\
\text { autogamy }\end{array}$} & \multicolumn{2}{|c|}{$\begin{array}{l}\text { Spontaneous } \\
\text { autogamy }\end{array}$} \\
\hline & & & & ZAB1 & OPA1 & ZAB1 & OPA1 \\
\hline 2007 & $\begin{array}{c}3 / 21 \\
\mathbf{9 0 . 0} \pm 17.32\end{array}$ & $\begin{array}{c}3 / 29 \\
\mathbf{0} \pm 0.00\end{array}$ & 2007 & $\begin{array}{c}2 / 22 \\
\mathbf{7 8 . 5} \pm 16.26\end{array}$ & $\begin{array}{c}2 / 33 \\
\mathbf{8 0 . 0} \pm 28.28\end{array}$ & $\begin{array}{c}3 / 93 \\
\mathbf{0} \pm 0.00\end{array}$ & $\begin{array}{c}1 / 8 \\
0 \pm 0.00\end{array}$ \\
\hline \multirow[t]{3}{*}{2008} & $\begin{array}{c}3 / 13 \\
\mathbf{8 0 . 0} \pm 20.00\end{array}$ & $\begin{array}{c}2 / 11 \\
\mathbf{0} \pm 0.00\end{array}$ & 2008 & $\begin{array}{c}1 / 29 \\
\mathbf{2 4 . 1} \pm 0.00\end{array}$ & $\begin{array}{c}3 / 86 \\
\mathbf{7 0 . 3} \pm 29.50\end{array}$ & $\begin{array}{c}2 / 55 \\
\mathbf{0} \pm 0.00\end{array}$ & $\begin{array}{c}4 / 99 \\
\mathbf{1 0 . 7} \pm 12.42\end{array}$ \\
\hline & & & 2009 & - & - & $\begin{array}{c}5 / 161 \\
0.7 \pm 1.65\end{array}$ & - \\
\hline & & & 2010 & - & - & $\begin{array}{c}6 / 168 \\
0 \pm 0.00\end{array}$ & - \\
\hline
\end{tabular}

Orchideae

Gymnadenia conopsea

Platanthera bifolia

\begin{tabular}{|c|c|c|c|c|c|c|c|}
\hline \multirow{2}{*}{ year } & \multirow{2}{*}{$\begin{array}{c}\begin{array}{c}\text { Induced } \\
\text { autogamy }\end{array} \\
\text { ZAB2 }\end{array}$} & \multirow{2}{*}{$\begin{array}{c}\begin{array}{c}\text { Spontaneous } \\
\text { autogamy }\end{array} \\
\text { ZAB2 }\end{array}$} & \multirow{2}{*}{ year } & \multicolumn{2}{|c|}{$\begin{array}{c}\text { Induced } \\
\text { autogamy }\end{array}$} & \multicolumn{2}{|c|}{$\begin{array}{l}\text { Spontaneous } \\
\text { autogamy }\end{array}$} \\
\hline & & & & ZAB1 & POG & ZAB1 & POG \\
\hline 2007 & - & $\begin{array}{c}2 / 93 \\
\mathbf{9 . 4} \pm 2.96\end{array}$ & 2007 & $\begin{array}{c}4 / 48 \\
\mathbf{1 0 0 . 0} \pm 0.00\end{array}$ & $\begin{array}{c}3 / 46 \\
100.0 \pm 0.00\end{array}$ & - & $\begin{array}{c}1 / 22 \\
\mathbf{0} \pm 0.00\end{array}$ \\
\hline 2008 & $\begin{array}{c}2 / 52 \\
100.0 \pm 0.00\end{array}$ & $\begin{array}{c}4 / 171 \\
\mathbf{1 9 . 0} \pm 12.96\end{array}$ & 2008 & $\begin{array}{c}1 / 20 \\
100.0 \pm 0.00\end{array}$ & $\begin{array}{c}2 / 33 \\
\mathbf{9 1 . 0} \pm 2.82\end{array}$ & $\begin{array}{c}3 / 38 \\
\mathbf{0} \pm 0.00\end{array}$ & $\begin{array}{c}3 / 58 \\
\mathbf{0} \pm 0.00\end{array}$ \\
\hline
\end{tabular}

$\mathrm{N} / \mathrm{n}$ - examined inflorescences/flowers; mean value of fruit set (calculated per inflorescence) in \% (in bold) $\pm \mathrm{SD}$. 
on the inflorescence as the most appropriate method (Tremblay et al., 2005). The possibility of spontaneous autogamy was checked on flowers without any treatment. As the plants in the particular experiment started fruiting, the mature and strongly swollen capsules were counted. If the shape or size of the fruit was abnormal, we collected it to check whether seeds were formed. We accepted capsules that contained any number of seeds. Fruit set was correlated with the position on the inflorescence (bottom, middle and upper) to account for resource limitations on reproductive success, which is commonly discussed for orchids (Tremblay et al., 2005).

\section{SEED QUANTITY AND QUALITY}

Strongly swollen, fresh, undeformed and undamaged fruits were collected just before opening from suitable inflorescences exposed to hand pollination in 2007 for C. rubra, N. ovata, and P. bifolia, and in 2008 for $G$. conopsea. The fruit position on the inflorescence was also recorded. The total number of all seeds removed from the capsule was counted using paper divided into narrow triangles on a Petri dish. Seeds were classified as properly formed or defective based on the embryo shape, color, and abortion of ovules (Goodwillie and Knight, 2006). The seed number and quality (across populations and years) were correlated with the position on the inflorescence (bottom, middle and upper) to account for resource limitation.

\section{RESULTS}

\section{INDUCED AUTOGAMY}

High levels of fruit set were noted in the populations of the four orchid species as a result of induced self-pollination with pollen taken from the same flower (Tab. 2). The value of fruiting was $100 \%$ in G. conopsea and $98.2 \%$ in P. bifolia (the highest), and $69.0 \%$ in $N$. ovata (the lowest). In C. rubra, $85.0 \%$ of self-pollinated flowers developed into fruits. In $P$. bifolia, almost every flower except for three individuals was successfully fertilized after artificial auto-pollination in each year and site. The most variable results were observed for $N$. ovata during both years and within both populations (Tab. 2). The highest fruit set per inflorescence (100\%) was recorded twice in this species on individuals in the OPA 1 population in 2007 and 2008. The lowest fruit set per inflorescence was noted in 2008 in the ZAB1 and OPA1 populations ( $24 \%$ and $41 \%$, respectively). For all the species, the fruit set was independent of the flower position on the inflorescence (Spearman's rank correlation, $P>0.05)$.

\section{SPONTANEOUS AUTOGAMY}

Only in the population of $G$. conopsea, fruits were recorded on each of the bagged inflorescences. In total, 31 fruits were developed from 171 flowers of $G$. conopsea. The fruiting level reached $29.3 \%$ and $31.4 \%$ on two inflorescences. On the remaining inflorescences, the fruit set was $5.0 \%, 7.3 \%, 10.9 \%$, and $10.9 \%$. In the populations of C. rubra and $P$. bifolia, no capsule developed due to spontaneous self-pollination (Tab. 2). Fruits probably resulting from spontaneously self-pollinated flowers were recorded in both populations of $N$. ovata on 3 inflorescences and 10 flowers, which represent $14 \%$ of all the plants and $1.7 \%$ of all the flowers examined in this experiment (Tab. 2). However, thrip larvae were found during microscopic observation of autogamous fresh flowers and fruits (Fig. 1).

\section{SEED QUANTITY AND QUALITY AFTER INDUCED AUTOGAMY}

Among the studied orchids, all seeds were normally developed only in C. rubra. The highest frequency of incorrectly formed seeds (almost 14\%) was documented in $G$. conopsea. In $N$. ovata and $P$. bifolia, the mean percentage of abnormal seeds per capsule did not exceed $3 \%$, but in P. bifolia, the percentage was more variable between the analyzed fruits (Tab. 3). In both representatives of the Neottieae tribe, seed production was independent of fruit position on the inflorescence (Spearman's rank correlation, $P>0.05)$. In $P$. bifolia, there was a significantly reduced number of seeds in the capsule $(\mathrm{R}=-0.43, P<0.001)$ and of seeds with a well-developed embryo from the bottom up $(\mathrm{R}=-0.42, P<0.001)$. Similarly, in $G$. conopsea, capsules that were higher situated contained a significantly larger number of incorrectly formed seeds in comparison to capsules at lower positions on the inflorescence ( $\mathrm{R}=0.37, P<0.05$ ).

\section{DISCUSSION}

\section{INDUCED AUTOGAMY}

Our results show that each of the analyzed orchid species is self-compatible. Although many authors report this information, empirical estimations are scarce. In the case of C. rubra, we did not find any other information on the subject apart from our own results. However, self-compatibility was reported by Pedersen et al. (2009) in the related Cephalanthera exigua $(72.7 \%$ fruiting from 11 artificially self-pollinated flowers) and by Chung et al. (2004) for Cephalanthera longibracteata (without any empirical data). For N. ovata, the 


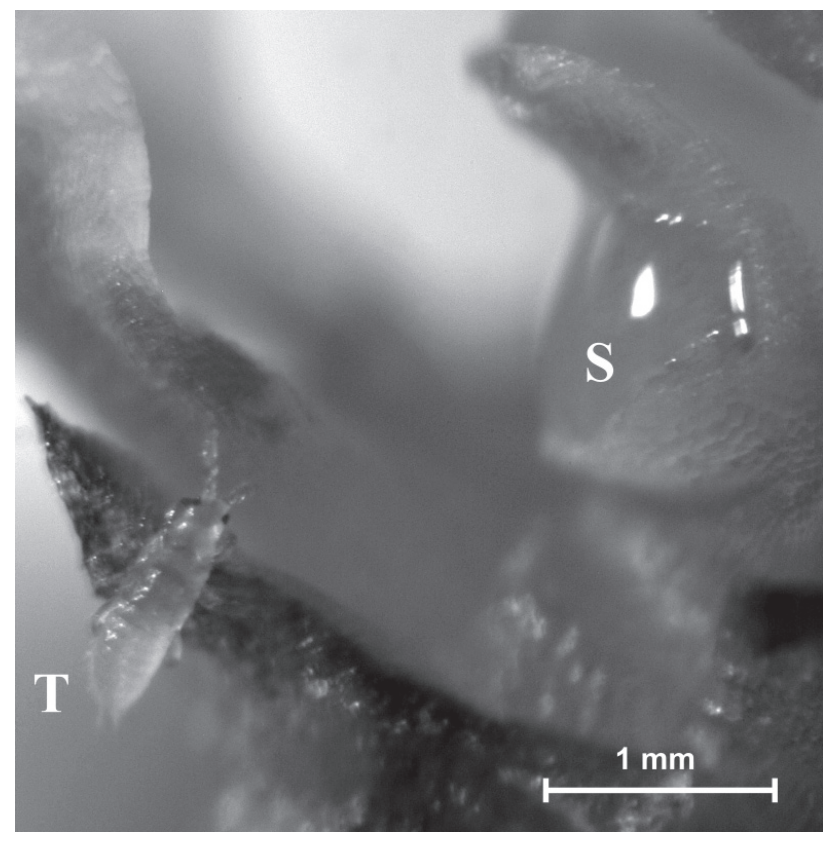

Fig. 1. Thrip larva (Thysanoptera) on Neottia ovata gynostemium. S - stigma, T - thrip.

high fruiting level noted after induced autogamy confirms the results after experimental pollination in Sweden (100\% fruiting from 27 flowers) (Nilsson, 1981 ) and Belgium (> 97.5\% fruiting level, without information on how many flowers were handpollinated) (Brys et al., 2008). Self-compatibility in this species was also reported for populations located in Germany (Müller, 1868) and the Czech Republic (Procházka and Velísek, 1983), also without any quantitative data.

The very high fruiting level that we noted regularly after induced autogamy in $P$. bifolia corroborates our previous results (Brzosko et al., 2009), as well as findings from Swedish populations reporting $100 \%$ fruit set from 27 handpollinated flowers (Nilsson, 1983a) and almost complete self-pollination in 41 individuals (Boberg and Ågren, 2009). All hand-self-pollinated flowers of $G$. conopsea that were successfully developed into mature fruits in populations from the Biebrza valley clearly correspond with the information about the self-compatible system in this species from Sweden (Gustafsson, 2000), Switzerland (Huber et al., 2005), the Czech Republic (Jersáková et al., 2010), and Norway (Sletvold and Ågren, 2011). Nevertheless, no quantitative results were previously given.

Differences in the level of fruiting obtained for particular species may be associated with different flower longevity. Flowers of C. rubra and $N$. ovata remain receptive for shorter periods than those of G. conopsea and P. bifolia (Darwin, 1877; Vallius et al., 2006; Claessens and Kleynen, 2011). Therefore, there is a greater probability of pollinating unreceptive flowers in the first two species than in the last two. Additionally, we also paid attention to the sensitivity to habitat conditions for $N$. ovata, which had the most variable fruit set. In both populations of this species, we observed aborted buds at different positions on the inflorescence. Flower bud abortion in Epipactis helleborine has been linked to drought conditions (Light and MacConaill, 1994). Insufficient moisture at a critical time (very often in the previous year) has been found to have negative effects on the flowering and reproductive success of a number of terrestrial orchids, including $N$. ovata (Inghe and Tamm, 1988).

Given all the possible causes of variation in reproductive success at different geographical sites, the number and quality of autogamous seeds that we found for C. rubra and $N$. ovata indicate very low levels of post-pollination mortality and complete self-compatibility of these species.

TABLE 3. Seed number and quality of fruits after induced autogamy.

\begin{tabular}{|c|c|c|c|c|c|c|c|c|}
\hline \multirow{2}{*}{ species } & \multirow[b]{2}{*}{$\boldsymbol{N}_{p}$} & \multirow[b]{2}{*}{$\boldsymbol{N}_{f}$} & \multicolumn{3}{|c|}{ No. of all seed sets } & \multicolumn{3}{|c|}{ Percentage of deformed embryos } \\
\hline & & & $\bar{x}$ & SD & Range & $\bar{x}$ & SD & Range \\
\hline \multicolumn{9}{|l|}{ Neottieae } \\
\hline C. rubra & 3 & 18 & 4532.3 & 2905.38 & $341-8482$ & 0.0 & - & - \\
\hline N. ovata & 4 & 20 & 838.8 & 421.54 & $218-1774$ & 1.2 & 1.30 & $0.0-4.1$ \\
\hline \multicolumn{9}{|l|}{ Orchideae } \\
\hline P. bifolia & 5 & 66 & 1401.7 & 819.28 & $138-3784$ & 2.6 & 8.43 & $0.0-56.5$ \\
\hline G. conopsea & 2 & 38 & 1826.2 & 331.62 & $905-2613$ & 13.7 & 22.24 & $0.1-90.2$ \\
\hline
\end{tabular}

$N_{p}$ - number of examined inflorescences, $N_{f}$ - number of examined fruits. 
Because deceptive pollination is strongly pollen limited, the mean seed number per capsule after hand pollination in C. rubra was higher than that reported after natural pollination (3224 seeds per fruit) (Nazarov, 1995). Conversely, the average seed number and range in $N$. ovata were the same as those noted from natural Ukrainian populations $(\bar{x}=825)$ (Vakhrameeva et al., 2008). In Nilsson's experiment performed on this species (Nilsson, 1981), the number and size of embryos after induced autogamy were also only slightly reduced, compared to the result of outcrossings. Because induced autogamy did not affect fertilized ovules developing in C. rubra at all and decreased only the quality of sporadic seed number in $N$. ovata, we suggest that early-stage inbreeding depression could be unimportant in both species.

Interestingly, we detected post-pollination selection in seed development for both Orchideae species. Unexpectedly, we noted a reduction by several times in the selfed seed set of $P$. bifolia, compared to natural populations reported from different regions and types of plant communities in Russia and Ukraine (the mean seed number per capsule varied from 3666 and 3971 to 5384) (Vakhrameeva et al., 2008). Similarly, in Swedish populations, Nilsson (1983a) recorded a 56.2\% occurrence of indistinct embryos of a smaller size after induced autogamy, which has been connected with unfertilized ovules (Levin, 1989; Goodwillie and Knight, 2006). Such a significant lack of fertilized ovules suggests pre-zygotic selection and partial self-compatibility. This was also noted for Platanthera chlorantha (Nilsson, 1983a) or Orchis mascula (Nilsson, 1983c).

In the case of $G$. conopsea, the mean seed number per capsule was the same as that in naturally developed fruits in the ZAB2 population observed in 2013 (Tałałaj and Skierczyński, 2015). A similar level of 2044 seeds was also obtained after natural pollination by Salisbury (1942) and 1675 seeds by Vakhrameeva et al. (2008). However, in this species, we observed post-zygotic selection based on the color and shape of the fertilizing embryo. Although we did not compare seeds between self- and cross-pollination, significant inbreeding depression in selfed seeds was detected in the populations of $G$. conopsea from the Czech Republic (Jersáková et al., 2010) and Switzerland (Huber et al., 2005). Resource limitation was also visible in both representatives of Orchideae, as the number of incorrectly formed seeds significantly increased from the bottom up on the inflorescence. It seems that resource limitation could magnify the expression of inbreeding depression in the higher flowers of both species from Orchideae (Dudash, 1990; Hayes et al., 2005; Goodwillie and Knight, 2006).

\section{SPONTANEOUS AUTOGAMY}

Besides the opportunity of autogamy in each of the studied orchids, spontaneous autogamy was noted only in N. ovata and G. conopsea. Hooker (1854) and Kugler (1963) considered the possibility of spontaneous autogamy in $N$. ovata. They supposed that if the pollinia become dry, a few tetrads may crumble away from the pollen mass and contact the stigma. Hooker (1854) also emphasized the role of glandular secretion in this self-pollination mechanism. However, even though the pollinia became compressed in older flowers, Claessens and Kleynen (2011) point out the role of the median anther wall and clinandrium in late autogamy prevention. A lack of spontaneous autogamy was also reported in natural populations of $N$. ovata (Hildebrand, 1863; Procházka and Velísek, 1983) and after a small bagging experiment (Brys et al., 2008).

We associated fruits observed under the net bag with the presence of thrip larvae (Thysanoptera), which we found on $N$. ovata flowers (Fig. 1). Despite the presence of the net bag, these insects can easily get in, which was also reported by Annand (1926). The role of thrips in the pollination of various plant species is well known (Annadurai and Velayudhan, 1986). Many thrips spend most of their entire adult and larval life in flowers. Although they are small ( 0.75 to $1.50 \mathrm{~mm}$ in length), they often occur in large numbers and may be are capable of carrying considerable amounts of pollen (Annand, 1926). Thrips are very infrequent pollen vectors from the anther with friable pollen to the stigma of N. ovata (Darwin, 1877; Nilsson, 1981). The thrip Taeniothrips picipes also infested most of the experimental flowers in Swedish populations (Nilsson, 1981).

G. conopsea is usually described as a pollinator-dependent orchid species. A lack of spontaneous autogamy was reported in populations from Sweden (Gustafsson, 2000), Switzerland (Huber et al., 2005), the Czech Republic (Jersáková et al., 2010), and Norway (Sletvold and Ågren, 2011). However, these papers gave no information about the number of pollinated flowers and inflorescences. By contrast, Campbell (1999) found in Britain that autogamy in this species is rare, and Meyer et al. (2007) reported a $36 \%$ of the fruit set after exclusion from pollinators in Germany. These results support our findings and indicate that G. conopsea could be a facultatively autogamous species, although the intensity of such a process in this orchid varies between sites.

To verify the mechanism and time of spontaneous autogamy in this species, we carried out further research in three populations from northeast Poland in 2013 (Tałałaj and Skierczyński, 
2015). Using a bagging experiment, we noted the stages of the anther thecae and the positions of the pollinaria at five phenological stages of the flower. We found that spontaneous autogamy in G. conopsea is accidental. Self-pollination may occur in flowers at each position on the inflorescence and at various flowering stages except for the beginning of anthesis. This phenomenon is caused by the bending of the caudicle and massulae disintegration, which is preceded by the gradual opening of the anther chamber (Tałałaj and Skierczyński, 2015).

Our previous findings are reaffirmed by the complete lack of fruit set in the deceptive and mimicking flowers of $C$. rubra that were experimentally untouched (Brzosko and Wróblewska, 2003). The lack of fruits due to the apparent lack of natural insect pollinators over 10 years in the British Isles (Newman et al., 2007) also confirms that this species depends completely on an insect vector for successful pollination. Nazarov (1995) and Scacchi et al. (1991) describe this species as allogamous and "a perfect outbreeder", respectively. However, because of the lack of rostellum, Hagerup (1952) considered spontaneous autogamy to be likely. On the other hand, Claessens et al. (2015) observed that autogamy in C. rubra may be caused by strong rainfall, when pollinia are soaked with water and dropped onto the stigma. The scenario of frequent selfing is ruled out by the low natural fruiting level of this species at various geographical sites and its variability (from 0 to $30 \%$ ) with respect to the presence or absence of bellflowers (Nilsson, 1983b; Procházka and Velísek, 1983; Tuulik, 1998; Brzosko and Wróblewska, 2003). The almost complete absence of spontaneous autogamy and the low, but variable fruit set (from 1 to $30 \%$ ) in communities without and with a model species were also observed for the deceptive and mimicking Cephalanthera longifolia (Dafni and Ivri, 1981). Such a low level of fruit set fits the scale of fruit set reported in the allogamous, nectarless, and temperate orchids (Neiland and Wilcock., 1998; Tremblay et al., 2005).

The lack of spontaneous autogamy observed for P. bifolia rejects the opposite result, which was noticed in 2001 in the ZAB population (Brzosko, 2003). Experimental studies performed during the six subsequent years in three populations on 19 ramets and 295 flowers (Brzosko et al., 2009) confirm that $P$. bifolia is an allogamous species. Similarly, no fruit was produced without vectormediated pollination on 92 flowers in Swedish populations (Nilsson, 1983a). We feel that fruit set under untouched net bags could be the result of a very small insect, as observed in $N$. ovata. There is a broad range of insects that feed and breed on orchids, including Platanthera (Light and MacConaill, 2011). Their larval form could pollinate the host flower or even induce pseudofruit formation, as in outcrossing Eulophia species (Peter and Johnson, 2009). Importantly, weather and habitat conditions influence the activity of these insects (Light and MacConaill, 2011), which could be the reason for the single events of capsule formation in P. bifolia without external pollinators.

\section{CONCLUSION}

Information about the breeding system, especially the possibility of autogamy, is usually considered essential in the majority of papers on orchid biology, ecology, evolution, genetics, phylogeny, and conservation. However, a transition from allogamy to autogamy, even at the population and individual level, is well known in Orchidaceae. Because such a transition is more probable within species from some Orchidaceae groups (e.g., the Neottieae tribe) than other more specialized groups (e.g., the Orchideae tribe), speculations about possible spontaneous self-pollination dominate for these representatives. In terms of self-compatibility (complete in C. rubra, N. ovata, and G. conopsea, and probably partial in $P$. bifolia), our results have shown that spontaneous autogamy is possible in only one Orchideae representative, G. conopsea. If selfing occurs, inbreeding depression and resource limitation manifesting at the seed level are revealed in only the Orchideae species.

\section{AUTHORS' CONTRIBUTIONS}

IT: field and laboratory study supervision, data analysis, conception and final drafting of manuscript, BO, EW and AR: field and laboratory work, EB: conceptual work, revision of manuscript.

\section{ACKNOWLEDGEMENTS}

We thank Piotr Tałałaj for preparing the figure. We are grateful to the Biebrza National Park for issuing research permits. The work was supported by the Department of Botany, Institute of Biology University of Białystok, from statutory research funds. 


\section{REFERENCES}

Annadurai RS, and Velayudhan R. 1986. Pollination potential of thrips (Insecta: Thysanoptera) in some fabaceous plants. Proceedings of the Indian Academy of Science 95: 745-750.

ANNAND PN. 1926. Thysanoptera and the pollination of flowers. Amererican Naturalist 60: 177-182.

BARRETt SCH, COLAUTTI RI, and ECKERT CG. 2008. Plant reproductive systems and evolution during biological invasion. Molecular Ecology 17: 373-383.

BARRETT SCH, and SHORE JS. 1989. Isozyme variation in colonizing plants. In: Soltis DE, and Soltis PS [ed.] Isozymes in plant biology, 127-145. Dioscorides Press, Portland, OR.

BATEMAN RM. 2001. Evolution and classification of European orchids: insights from molecular and morphological characters. Journal Europäischer Orchideen 33: 33-1 19.

Bell AK, Roberts DL, Hawkins JA, Rudall PJ, Box MS, and BATEMAN RM. 2009. Comparative micromorphology of nectariferous and nectarless labellar spurs in selected clades of subtribe Orchidinae (Orchidaceae). Botanical Journal of the Linnean Society 160: 369-387.

Boberg E, and ÅgRen J. 2009. Despite their apparent integration, spur length but not perianth size affects reproductive success in the moth-pollinated orchid Platanthera bifolia. Functional Ecology 23: 1022-1028.

Bonatti PM, Sgarbi E, and Del Prete C. 2006. Gynostemium micromorphology and pollination in Epipactis microphylla (Orchidaceae). Journal of Plant Research 119: 431-437.

Brys R, Jacguemyn H, and Hermy M. 2008. Pollination efficiency and reproductive patterns in relation to local plant density, population size and floral display in the rewarding Listera ovata (Orchidaceae). Botanical Journal of the Linnean Society 157: 713-721.

BRzosko E. 2002. The dynamics of Listera ovata populations on mineral islands in the Biebrza National Park. Acta Societatis Botanicorum Poloniae 71: 243-251.

Brzosko E. 2003. The dynamics of island populations of Platanthera bifolia in the Biebrza National Park (NE Poland). Annales Botanici Fennici 40: 243-253.

Brzosko E, and WróBlewsKa A. 2003. Genetic variation and clonal diversity in island Cephalanthera rubra populations from the Biebrza National Park, Poland. Botanical Journal of the Linnean Society 143: 99-108.

Brzosko E, WróBlewsKa A, TAŁAŁAJ I, and ADAMOWSKI W. 2009. Patterns of genetic diversity in Platanthera bifolia (Orchidaceae) with respect to life history traits and recent range expansion. Folia Geobotanica 44: 131-144.

CAMPBEll VV. 1999. Aspects of the molecular ecology and population biology of Gymnadenia conopsea (L.) R. Br. in Britain. Ph.D. dissertation, University of Sussex, Brighton.

Catling PM. 1990. Auto-pollination in the Orchidaceae. In: Arditti J [ed.] Orchid Biology: reviews and perspectives, 123-158. V. Timber Press, Portland, OR.

CHARLESworTH D. 2006. Evolution of plant breeding systems. Current Biology 16: 726-735.

Cheng J, Shi J, ShangGuan FZ, Dafni A, Deng ZH, and Luo YB. 2009. The pollination of a self-incompatible, food-mimic orchid, Coelogyne fimbriata (Orchidaceae), by female Vespula wasps. Annals of Botany 104: 565-571.

Chung MY, NAson JD, and Chung MG. 2004. Spatial genetic structure in populations of the terrestrial orchid Cephalanthera longibracteata (Orchidaceae). American Journal of Botany 91: 52-57.

Claessens J, and KLEYNen J. 2011. The flower of the European orchid. Form and function. Schrijen-Lippertz, Netherlands.

Claessens J, BeentJes KK, HeiJerman T, Miller J, and GravenDEEL B. 2015. Beobachtungen von Miarus campanulae als Bestäuber von Cephalanthera rubra. Journal Europäischer Orchideen 47: 77-87.

Dafni A. 1992. Pollination Ecology: A Practical Approach. Oxford University Press, Oxford.

DAFNI A, and IVRI Y. 1981. Floral mimicry between Orchis israelitica Baumann et Dafni (Orchidaceae) and Bellevalia flexuosa L. (Liliaceae). Oecologia 49: 229-232.

DARWIN C. 1877. The various contrivances by which orchids are fertilized by insects. John Murray, London.

DRESSLER RL. 1981. The orchids: natural history and classification. Harvard University Press, Cambridge, MA.

DUDASH MR. 1990. Relative fitness of selfed and outcrossed progeny in a SC, protandrous species, Sabatia angularis L. (Gentianaceae) a comparison in three environments. Evolution 44: 1129-1139.

Eckert CG, Kalisz S, Geber MA, Sargent R, Elle E, Cheptou PO, Goodwillie C, Johnston MO, Kelly JK, Moeller DA, Porcher E, Ree RH, Vallejo-Marín M, and Winn AA. 2009. Plant mating systems in a changing world. Trends in Ecology and Evolution 25: 35-43.

Etcheverry AV, Protomastro JJ, and Westerkamp C. 2003. Delayed autonomous self-pollination in the colonizer Crotalaria micans (Fabaceae: Papilionoideae): structural and functional aspects. Plant Systematics and Evolution 239: $15-28$.

Gale S. 2007. Autogamous seed set in a critically endangered orchid in Japan: pollination studies for the conservation of Nervilia nipponica. Plant Systematics and Evolution 286: 59-73.

Goodwillie C, and Knight MC. 2006. Inbreeding depression and mixed mating in Leptosiphon jepsonii: a comparison of three populations. Annals of Botany 98: 351-360.

Gustafsson S. 2000. Patterns of genetic variation in Gymnadenia conopsea, the fragrant orchid. Molecular Ecology 9: 1863-1872.

HAGERUP O. 1952. Bud autogamy in some northern orchids. Phytomorphology 2: 51-60.

Hayes CN, Winsor JA, and Stephenson AG. 2005. Environmental variation influences the magnitude of inbreeding depression in Cucurbita pepo ssp. texana (Cucurbitaceae). Journal of Evolutionary Biology 18: 147-155.

Hildebrand F. 1863. Die Fruchtbildung der Orchideen, ein Beweis für die doppelte Wirkung des Pollen. Botanische Zeitung 21: 337-345.

HoOKer JD. 1854. On the functions and structure of the rostellum of Listera ovata. Philosophical Transactions of the Royal Society of London 144: 259-263.

Huber FK, Kaiser R, SAuter W, and Schiestl FP. 2005. Floral scent emission and pollinator attraction in two species of Gymnadenia (Orchidaceae). Oecologia 142: 564-575. 
IngHe O, and TAMm CO. 1988. Survival and flowering of perennial herbs. V. Patterns of flowering. Oikos 51: 203-219.

Jersáková J, Castro S, Sonk N, Milchreit K, SchödelbauEROVÁ I, TOlasch T, and DötTERL S. 2010. Absence of pollinator-mediated premating barriers in mixed-ploidy populations of Gymnadenia conopsea s.l. (Orchidaceae). Evolutionary Ecology 24: 1199-1218.

JoHnson SD, and NiLSSON LA. 1999. Pollen carryover, geitonogamy, and the evolution of deceptive pollination systems in orchids. Ecology 80: 2607-2619.

KAlisz S, and Vogler DW. 2003. Benefits of autonomous selfing under unpredictable pollinator environments. Ecology 84: 2928-2942.

Kalisz S, Vogler D, Fails B, Finer M, Sheppard E, Herman T, and GonZales R. 1999. The mechanism of delayed selfing in Collinsia verna (Scrophulariaceae). American Journal of Botany 86: 1239-1247.

KotilíneK M, TĚŠitelová T, JERSÁKOVÁ J. 2015. Biological Flora of the British Isles: Neottia ovata. Journal of Ecology 103: 1354-1366.

KugLER H. 1963. UV-Musterungen auf Blüten und ihr Zustandekomme. Planta 59: 296-329.

LEVIN DA. 1989. Inbreeding depression in partially self-fertilizing phlox. Evolution 43: 1417-1423.

Light MHS, and MACConAILl M. 1994. Climate correlations with patterns of appearance of Epipactis helleborine (L.) Crantz. In: Brederoom P, Kapteyn den Boueester DW [ed.], Eurorchis 92, 30-44. Stichting Uitgeverij Koninklijke Nederlandse Natuurhistorische Vereniging, Utrecht/ Haarlem.

Light MHS, and MacConaill M. 2011. Potential impact of insect herbivores on orchid conservation. European Journal of Environmental Sciences 1(2): 115-124.

Liu KW, Liu ZJ, Huang LQ, Li LQ, Chen LJ, and Tang GT. 2006. Self-fertilization strategy in an orchid. Nature 441: 945-946.

LLOYD DG, and Schoen DJ. 1992. Self- and cross-fertilization in plants. I. Functional dimensions. International Journal of Plant Sciences 153: 358-369.

MAAD J, and NILSSON LA. 2004. On the mechanism of floral shifts in speciation: gained pollination efficiency from tongue- to eye-attachment of pollinia in Platanthera (Orchidaceae). Biological Journal of the Linnean Society 83: 481-495.

MARHOld K, Jongepierová I, KRAhulcová A, and KuČERA J. 2005. Morphological and karyological differentiation of Gymnadenia densiflora and G. conopsea in the Czech Republic and Slovakia. Preslia 77: 159-176.

Meyer B, Kröger J, and StefFan-Dewenter I. 2007. Contribution of diurnal and nocturnal pollinators to the reproductive success of the orchid species Gymnadenia conopsea. Entomologia Generalis 30: 299-300.

MÜLLER H. 1868. Beobachtungen an westfälischen Orchideen. Verhandlungen des Naturhistorischen Vereins der Preussischen Rheinlande und Westphalens 25: 1-62.

NAZAROV VV. 1995. Reproduction biology of orchids in the Crimea. Ph.D. dissertation, Komarov Botanical Institute, St. Petersburg, Russia.

NAZAROV VV, and IvANOv SP. 1990. Učastie pčel roda Chelostoma Latr. (Hymenoptera, Megachilidae) v opylenii mimikrirujuščix vidov Cephalanthera rubra (Z.) Rich. i Campanula taurica Już. v Krymu. Éntomologicheskoe Obozrenie 69: 534-537.

NEILAND MRM, and WILCOCK CC. 1998. Fruit set, nectar reward, and rarity in the Orchidaceae. American Journal of Botany 85: 1657-1671.

Newman RD, Showler AJ, Harvey MC, and Showler DA. 2007. Hand pollination to increase seed-set of red helleborine Cephalanthera rubra in the Chiltern Hills, Buckinghamshire, England. Conservation Genetics 4: 88-93.

NiLsson LA. 1981. The pollination ecology of Listera ovata (Orchidaceae). Nordic Journal of Botany 1: 461-480.

NiLSSON LA. 1983a. Processes of isolation and introgressive interplay between Platanthera bifolia (L.) Rich and P. chlorantha (Custer) Reichb. (Orchidaceae). Botanical Journal of the Linnean Society 87: 325-350.

NiLsson LA. 1983b. Mimesis of bellflower (Campanula) by the red helleborine orchid Cephalanthera rubra. Nature 305: 799-800.

NiLsson LA. 1983c. Anthecology of Orchis morio (Orchidaceae). Nordic Journal of Botany 3: 157-179.

PEAKALl R. 2007. Speciation in the Orchidaceae: confronting the challenges. Molecular Ecology 16: 2834-2837.

Pedersen HÆ, and EhLERS BK. 2000. Local evolution of obligate autogamy in Epipactis helleborine subsp. neerlandica (Orchidaceae). Plant Systematics and Evolution 223: 173-83.

Pedersen HÆ, Watthana S, Roy M, Suddee S, and Selosse M-A. 2009. Cephalanthera exigua rediscovered: new insights in the taxonomy, habitat requirements and breeding system of a rare mycoheterotrophic orchid. Nordic Journal of Botany 27: 460-468.

Percival MS. 1961. Types of nectar in angiosperms. New Phytologist 60: 235-281.

Peter CI, and Johnson SD. 2009. Autonomous self-pollination and pseudo-fruit set in South African species of Eulophia (Orchidaceae). South African Journal of Botany 75: 791-797.

Pridgeon AM, Cribb PJ, Chase MW, and Rasmussen FN (eds.). 2001. Genera Orchidacearum, Volume 2. Orchidoideae (Part 1). Oxford University Press, Oxford.

Pridgeon AM, Cribi PJ, Chase MW, and Rasmussen FN (eds.). 2005. Genera Orchidacearum, Volume 4: Epidendroideae (Part 1). Oxford University Press, Oxford.

PRocházKa F, and Velísek V. 1983. Orchideje naší pǔrody. Akademia, Praha.

Ramírez SR, Gravendeel B, Singer RB, Marshall CR, and PIERCE NE. 2007. Dating the origin of the Orchidaceae from a fossil orchid with its pollinator. Nature 448: 1042-1045.

RichaRdS A.J. 1997. Plant breeding systems. Chapman \& Hall, London.

SAlisbuRY EJ. 1942. The reproductive capacity of plants: studies in Quantitative biology. G. Bell and Sons, London.

Scacchi R, De Angelis G, and Corbo RM. 1991. Effect of the breeding system on the genetic structure in three Cephalanthera spp. (Orchidaceae). Plant Systematics and Evolution 176: 53-61.

SletVOld N, and ÅgREN J. 2011. Among-population variation in costs of reproduction in the long-lived orchid Gymnadenia conopsea: an experimental study. Oecologia 167: 461-468. 
Sguirrell J, Hollingsworth PM, Bateman RM, Tebbitt MC, and Hollingsworth ML. 2002. Taxonomic complexity and breeding system transitions: conservation genetics of the Epipactis leptochila complex (Orchidaceae). Molecular Ecology 11: 1957-64.

Suetsugu K. 2013. Delayed autonomous self-pollination in two Japanese varieties of Epipactis helleborine (Orchidaceae). Botanical Journal of the Linnean Society 173: 733-743.

SummerhaYes VS. 1951. Wild Orchids of Britain. Collins, London.

Stark G, Michalski SG, Babik W, Winterfeld G, and Durka W. 2011. Strong genetic differentiation between Gymnadenia conopsea and G. densiflora despite morphological similarity. Plant Systematics and Evolution 293: 213-226.

StPicZYŃsKa M, and Matusiewicz J. 2001. Anatomy and ultrastructure of spur nectary of Gymnadenia conopsea (L.) Orchidaceae. Acta Societatis Botanicorum Poloniae 70: 267-272.

SzlachetKo DL. 1995. Systema Orchidalium. Fragmenta Floristica et Geobotanica Supplementum 3: 1-152.

TAŁAŁAJ I, and BRZOSKO E. 2008. Selfing potential in Epipactis palustris, E. helleborine and E. atrorubens (Orchidaceae). Plant Systematics and Evolution 276: 21-29.

TAŁAŁAJ I, and SKIERCZYŃSKI M. 2015. Mechanism of spontaneous autogamy in the allogamous lepidopteran orchid Gymnadenia conopsea (L.) R. Br. (Orchidaceae). Acta Biologica Cracoviensia Series Botanica 57(1): 130-140.
Trávníček P, Jersáková J, KubÁtová B, KrejČíková J, BATeman RM, LuČANOVÁ M, KRAJNíKovÁ E, TĚŠitelová T, ŠTípKová Z, AmardeIlH JP, Brzosko E, JERmaKowicz E, CAbanne O, Durka W, Efimov P, Hedrén M, Hermosilla CE, Kreutz K, Kull T, Tali K, Marchand O, Rey M, Schiestl FP, ČURN V, and SUDA J. 2012. Minority cytotypes in European populations of the Gymnadenia conopsea complex (Orchidaceae) greatly increase intraspecific and intrapopulation diversity. Annals of Botany 110: 977-986.

Tremblay R, ACKerman JD, Zimmerman JK, and Calvo RN. 2005. Variation in sexual reproduction in orchids and its evolutionary consequences: a spasmodic journey to diversification. Biological Journal of the Linnean Society 84: 1-54.

TuUlık KT. 1998. Hiiumaa orchideed. Biosfääri Kaitseala Hiiumaa Keskus. Pirrujaak 5: 1-134.

Vakhrameeva MG, Tatarenko IV, Varlygina TI, Torosyan GK, and ZAGULSKII MN. 2008. Orchids of Russia and Adjacent Countries (within the borders of the former USSR). A.R.G. Gantner Verlag, Ruggell, Liechtenstein.

Vallius E, ARminen S, and Salonen V. 2006. Are there fitness advantages associated with a large inflorescence in Gymnadenia conopsea ssp. conopsea? http://www.r-b-o.eu/ rbo_public?Vallius_et_al_2006.html

Vӧтн W. 2000. Gymnadenia, Nigritella und ihre Bestäuber. Journal Europäischer Orchideen 32: 547-563.

ŻUREK S. 1991. Biebrza valley geomorphology. Zeszyty Problemowe Postępów Nauk Rolniczych 372: 29-62. 